\title{
Production of Corundum-Mullite Mixture with High Added Value from Raw Materials of Morocco
}

\author{
S. El Kalakhi' ${ }^{1}$, A. Samdi ${ }^{1}$, R. Moussa ${ }^{1}$, M. Gomina ${ }^{2}$ \\ ${ }^{1}$ EMPM-LPCMI, Faculté des Sciences Ain Chock, Casablanca, Maroc \\ ${ }^{2}$ CRISMAT, UMR 6508 ENSICAEN/CNRS, Caen Cedex, France \\ Email: azdn.samdi@gmail.com
}

Received 24 May 2016; accepted 27 June 2016; published 30 June 2016

Copyright (C) 2016 by authors and Scientific Research Publishing Inc.

This work is licensed under the Creative Commons Attribution International License (CC BY).

http://creativecommons.org/licenses/by/4.0/

(c) (i) Open Access

\begin{abstract}
In search of new mineral raw materials with industrial potential, we identified a deposit located in the southwest of Oujda (in the Northeastern Morocco). The physicochemical analyses indicate that the ore consists mainly of diaspore, topaz and quartz, and also secondary minerals. The presence of topaz in the ore is explained by hydrothermal action on the structure of diaspore. The investigation of structural transformations reveals complex reaction mechanisms that result in a mixture of corundum-mullite at $1200^{\circ} \mathrm{C}$, which is of great industrial interest. Thus, the peculiarity of this ore is the presence of fluorine and secondary minerals.
\end{abstract}

\section{Keywords}

Diaspore, Topaz, Corundum, Mullite, Structural Transformations

\section{Introduction}

Ceramic alumina are widely used as structural materials for applications requiring good mechanical strength, good wear resistance and good behavior under the influence of severe conditions in terms of mechanical stress often coupled to thermal shock in highly corrosive environments [1] [2].

One of the current trends in order to improve the performance of these materials is the development of mixed ceramic alumina-mullite, namely materials composed of two crystalline phases.

Mullite is a characteristic constituent of ceramics produced from aluminosilicates. It is the only stable compound in the diagram $\mathrm{SiO}_{2}-\mathrm{Al}_{2} \mathrm{O}_{3}$. It is with excellent physical properties: high melting temperature, low coefficient of expansion, good creep resistance, bending strength and thermal shock resistance, high chemical inert- 
ness [3] [4].

Mixed ceramic alumina-mullite is widely as refractory materials for the coating of high temperature furnaces.

Several routes of preparation are used: either by sintering at $1500^{\circ} \mathrm{C}$ of mixtures of commercial oxides of silica and alumina [5] or from natural raw materials such as kaolin and bauxite [6] [7]. In the latter case, the material consists of crystalline alumina and mullite phase and a glassy phase in which the different impurities are confined $\left(\mathrm{Fe}_{2} \mathrm{O}_{3}, \mathrm{CaO}, \mathrm{TiO}_{2}, \ldots\right)$. It is in this last part that fits our work. We intend to develop materials mixed alumina-mullite by thermal treatment up to $1200^{\circ} \mathrm{C}$ from a local clay with high potential, high diaspore $\mathrm{AlOOH}$ and topaz associated with quartz and argillaceous phases such as kaolinite.

Geological and petrographic work carried out on this deposit indicating a complexity regarding the mineralogical composition, structure, distribution of minerals identified on the site and their variability [8].

\section{Materials and Methods}

From geological data previously set by the Moroccan National Office of Hydrocarbons and Mines (ONHYM), we collected three samples referenced as G1, G2 and G3:

- G1 is made up of compact greyish gloss shine dense rocks,

- G2 consists of friable whitish to pinkish rocks,

- G3 consists of two types of rocks. The first shade is made of well differentiated whitish to gray very compact rocks and well individualized crystals. The second shade is composed of loose rock clusters of the same color than the first one.

In order to investigate the scope of these samples in industry, a set of characterizations were performed:

- quantification of the main major elements by X-ray fluorescence using a MagixPRO/Panalytical spectrometer;

- mineralogical analysis by X-ray diffraction on powder using Siemens D500 apparatus equipped with $\lambda \mathrm{KCu} \alpha 1=1.541874$ Å detector;

- thermogravimetric analysis (TGA) using DTA-TGA Shimadzu DTG-60/60H type thermobalance at a heating rate of $5^{\circ} \mathrm{C} / \mathrm{min}$;

- thermal expansion analysis by using a Setaram apparatus with a heating rate of $5^{\circ} \mathrm{C} / \mathrm{min}$;

- mechanical compression tests by using an universal testing machine equipped with a $10 \mathrm{kN}$ capacity load cell (Instron 5566 type).

\subsection{Quantitative Chemical Analysis}

The quantitative chemical analysis data are reported in Table 1. Note that silica $\left(\mathrm{SiO}_{2}\right)$ is the major oxide in G1 that shows a low fire loss. The alumina content in G2 is lower than G3 but the flux contents are slightly higher (alkali metal oxides $\mathrm{Na}_{2} \mathrm{O}$ and $\mathrm{K}_{2} \mathrm{O}$ ) and iron oxide $\mathrm{Fe}_{2} \mathrm{O}_{3}$. G3 shows special features compared to the other two. First the very high alumina content possibly indicates the presence of diaspore. This so high alumina content is strongly desired for refractory ceramic applications. Second, the important fire loss (11.2\%) can be connected to the high content of alumina hydrate.

\subsection{Mineralogical Characterization}

The X-ray diffraction spectra of the samples under study are shown in Figure 1. The detected minerals are: diaspore (D), illite (I), kaolinite (K), muscovite (Mu), quartz (Q) and topaz (T).

The mineral compositions of the samples G2 and G3 are similar. They are mainly composed of silica as

Table 1. Chemical composition of the samples (\% oxide mass).
\begin{tabular}{ccccccccccc}
\hline Oxydes & $\mathbf{S i O}_{2}$ & $\mathbf{A l}_{2} \mathbf{O}_{3}$ & $\mathbf{C a O}$ & $\mathbf{M g O}$ & $\mathbf{K}_{2} \mathbf{O}$ & $\mathbf{N a}_{2} \mathbf{O}$ & $\mathbf{F e}_{2} \mathbf{O}_{3}$ & $\mathbf{P}_{2} \mathbf{O}_{5}$ & $\mathbf{P F}^{*}$ & $\mathbf{\Sigma c}^{* *}$ \\
\hline $\mathbf{G 1}$ & $\mathbf{8 2 . 2 8}$ & 11.44 & 0.12 & 0.09 & 2.65 & 0.23 & 1.14 & 0.02 & 1.83 & 99.80 \\
$\mathbf{G 2}$ & 48.73 & $\mathbf{4 1 . 3 6}$ & 0.56 & 0.18 & 1.44 & 0.23 & 0.61 & 0.09 & $\mathbf{6 . 5 8}$ & 99.78 \\
$\mathbf{G 3}$ & 23.32 & $\mathbf{6 2 . 9 2}$ & 0.71 & 0.20 & 0.58 & 0.21 & 0.16 & 0.51 & $\mathbf{1 1 . 2 0}$ & 99.81 \\
\hline
\end{tabular}

${ }^{*}$ Lost on ignition at $1000^{\circ} \mathrm{C}$. ${ }^{* *}$ Total chemical composition. 


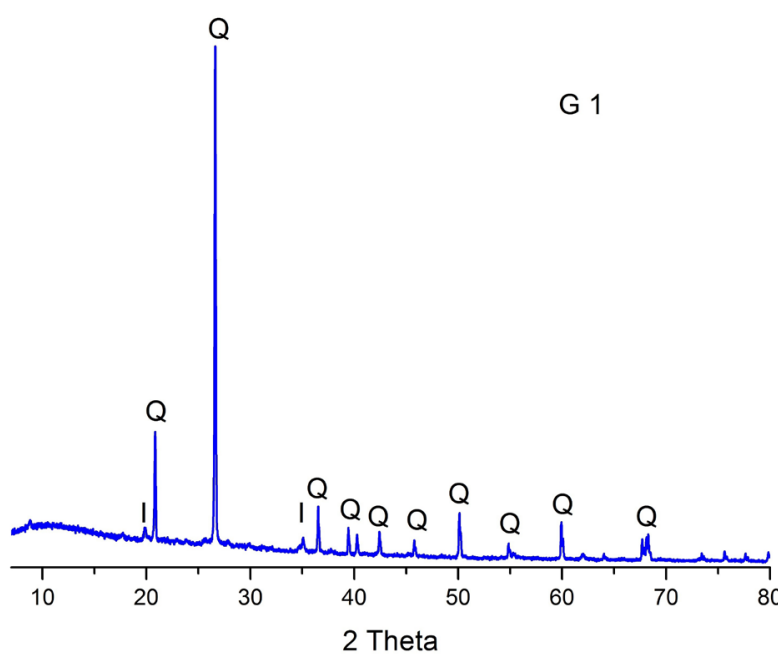

2 Theta

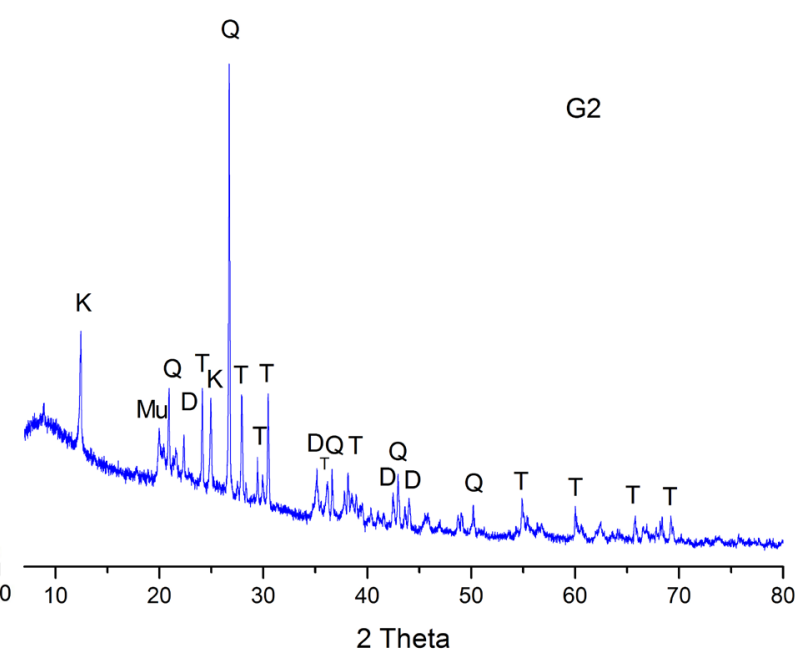

G3

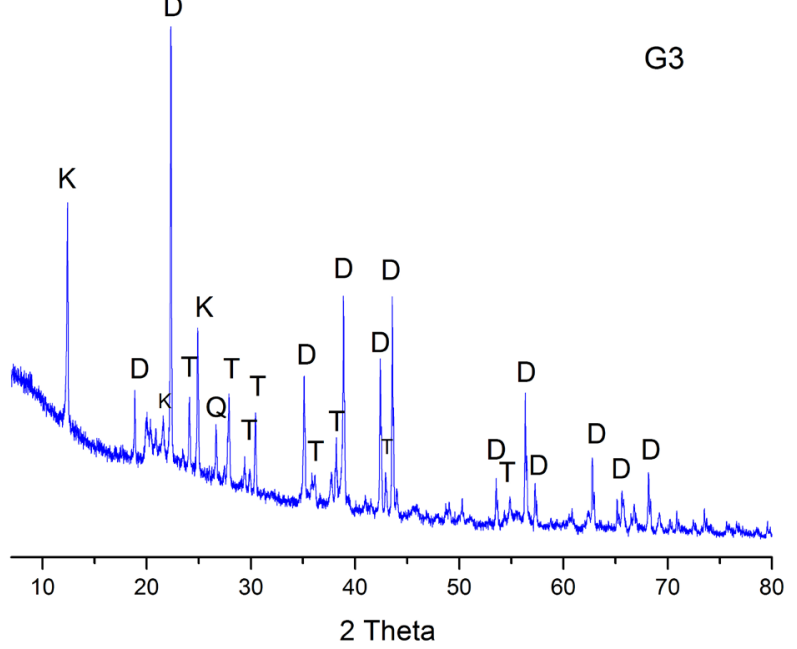

Figure 1. X-ray diffraction spectra of the different samples (D: Diaspore; I: Illite; K: Kaolinite; Mu: Muscovite; Q: Quartz; T: Topaz).

quartz, diaspore, topaz, muscovite and kaolinite. Muscovite is not detected by X-ray diffraction due to its low rate (low wt\% of $\mathrm{Na}_{2} \mathrm{O}$ and $\mathrm{K}_{2} \mathrm{O}$ ) in $\mathrm{G} 3$ while it is detectable in $\mathrm{G} 2$ (Figure 1). The qualitative mineralogical identification based on the results of the physico-chemical characterization of different samples is presented in Table 2.

Chemical and mineralogical analyzes show that G1 is composed mainly of quartz and poor in alumina, so this sample is of little interest for the intended purpose: the preparation of corundum-mullite mixed.

\subsection{Thermogravimetric Analysis (TGA)}

Figure 2 shows the evolution of the mass loss as a function of temperature for samples G2 and G3. The trends are similar although the total loss is higher for G3 (9\%) than for G2 (7\%). These losses can be explained considering three phenomena:

- the first phenomenon is the dehydration of the aluminium hydrate (the diaspore) according to the following dehydration reaction [9]-[11]:

$$
2 \alpha \mathrm{AlOOH}(\text { Diaspore }) \stackrel{570^{\circ} \mathrm{C}}{\longrightarrow} \alpha-\mathrm{Al}_{2} \mathrm{O}_{3}+\mathrm{H}_{2} \mathrm{O} \text {. }
$$

- the second phenomenon is the dihydroxylation of the kaolinite into metakaolinite:

$$
\mathrm{Si}_{2} \mathrm{Al}_{2} \mathrm{O}_{5}(\mathrm{OH})_{4}(\text { Kaolinite }) \stackrel{700^{\circ} \mathrm{C}}{\longrightarrow} \mathrm{Si}_{2} \mathrm{Al}_{2} \mathrm{O}_{7}+2 \mathrm{H}_{2} \mathrm{O} \text {. }
$$




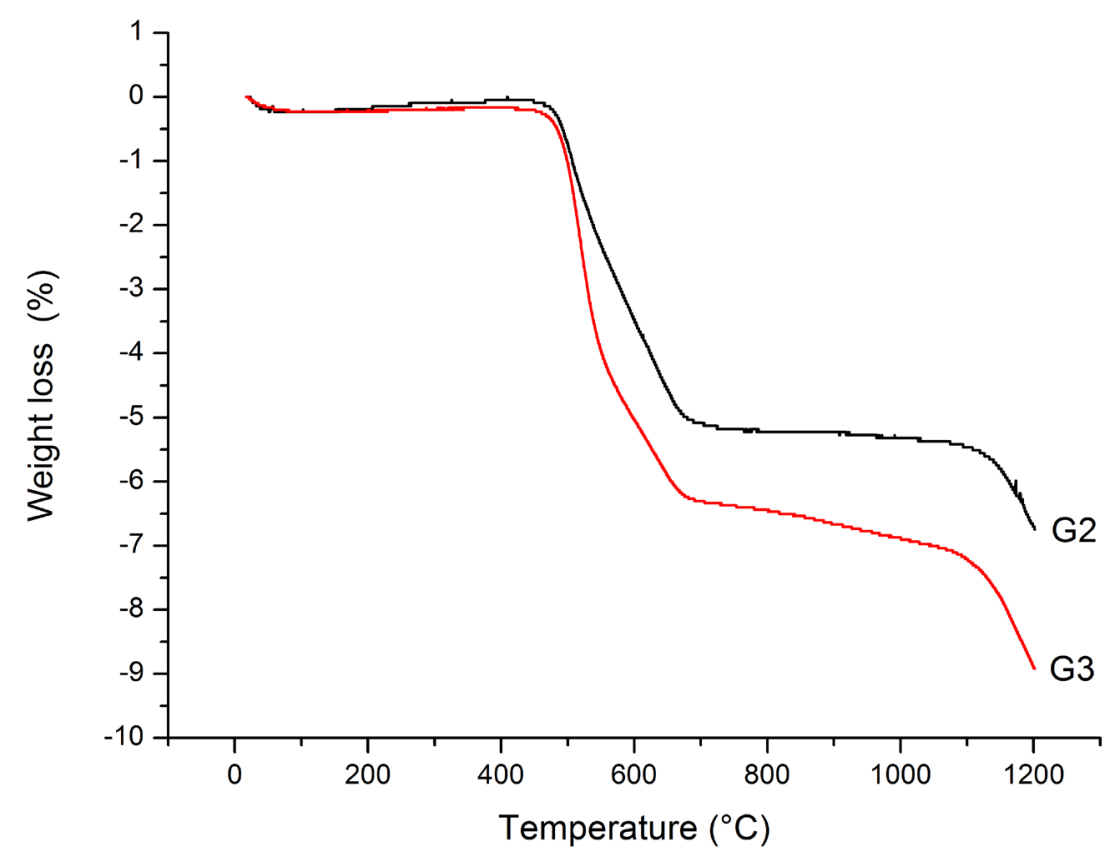

Figure 2. TGA curves recorded at a heating rate of $5^{\circ} \mathrm{C} / \mathrm{min}$ under air.

Table 2. Mineralogical composition (XRD) of the samples.

\begin{tabular}{ccccccc}
\hline Sample & Quartz & Illite & Kaolinite & Diaspore & Muscovite & Topaz \\
G 1 & X X X & X & -- & -- & -- & - \\
G 2 & X X X & -- & X X & X & X & X X \\
G 3 & X & -- & X X & X X X X & -- & X X X \\
\hline
\end{tabular}

To confirm these transformations, mineralogical determination was performed on G3 after exposure at $570^{\circ} \mathrm{C}$ and $700^{\circ} \mathrm{C}$. The results of this analysis are shown in Figure 3. It is apparent that the characteristic lines of the diaspore and those of the kaolinite disappear at $570^{\circ} \mathrm{C}$ and $700^{\circ} \mathrm{C}$, respectively. The difference between the drying temperature of the diaspore and the dihydroxylation temperature of the kaolinite as compared to those of the pure products can be explained by the complexity of field-collected samples.

- The third invoked phenomenon is the decomposition of the topaz into mullite at $1075^{\circ} \mathrm{C}$ according to R. A. Day et al. [12]:

$$
6 \mathrm{Al}_{2} \mathrm{SiO}_{4}\left(\mathrm{~F}_{0.75} \cdot \mathrm{OH}_{0.25}\right)_{2} \stackrel{1075^{\circ} \mathrm{C}}{\longrightarrow} 2\left(3 \mathrm{Al}_{2} \mathrm{O}_{3} \cdot 2 \mathrm{SiO}_{2}\right)+2 \mathrm{SiF}_{4}(\mathrm{~g})+\mathrm{HF}(\mathrm{g})+\mathrm{H}_{2} \mathrm{O}(\mathrm{g}) .
$$

\subsection{Thermal Expansion Behaviour}

The thermal behaviour is plotted in Figure 4(a) in terms of percent expansion as a function of the temperature for each sample:

- regarding the sample $\mathrm{G} 1$, the expansion occurring at around $580^{\circ} \mathrm{C}$ is attributed to the quartz $\alpha \rightarrow \beta$ transformation. The plateau observed in the range $600^{\circ} \mathrm{C}-900^{\circ} \mathrm{C}$ is characteristic of the presence of illite. The sharp contraction that occurs beyond $950^{\circ} \mathrm{C}$ indicates the beginning of sintering;

- $\quad$ G2 and G3 behave in the same way with:

-a slight thermal expansion up to $500^{\circ} \mathrm{C}$,

-followed by a slight decrease at $600^{\circ} \mathrm{C}$, which corresponds to the dehydroxylation reaction of kaolinite, -then occurs a dimensional stability in the temperature range $650^{\circ} \mathrm{C}-900^{\circ} \mathrm{C}$, -a second much steeper withdrawal occurs between $950^{\circ} \mathrm{C}$ and $1000^{\circ} \mathrm{C}$, followed by sintering up to $1200^{\circ} \mathrm{C}$. To better represent the withdrawal, Figure 4(b) shows the recorded withdrawal in percent as function of the 

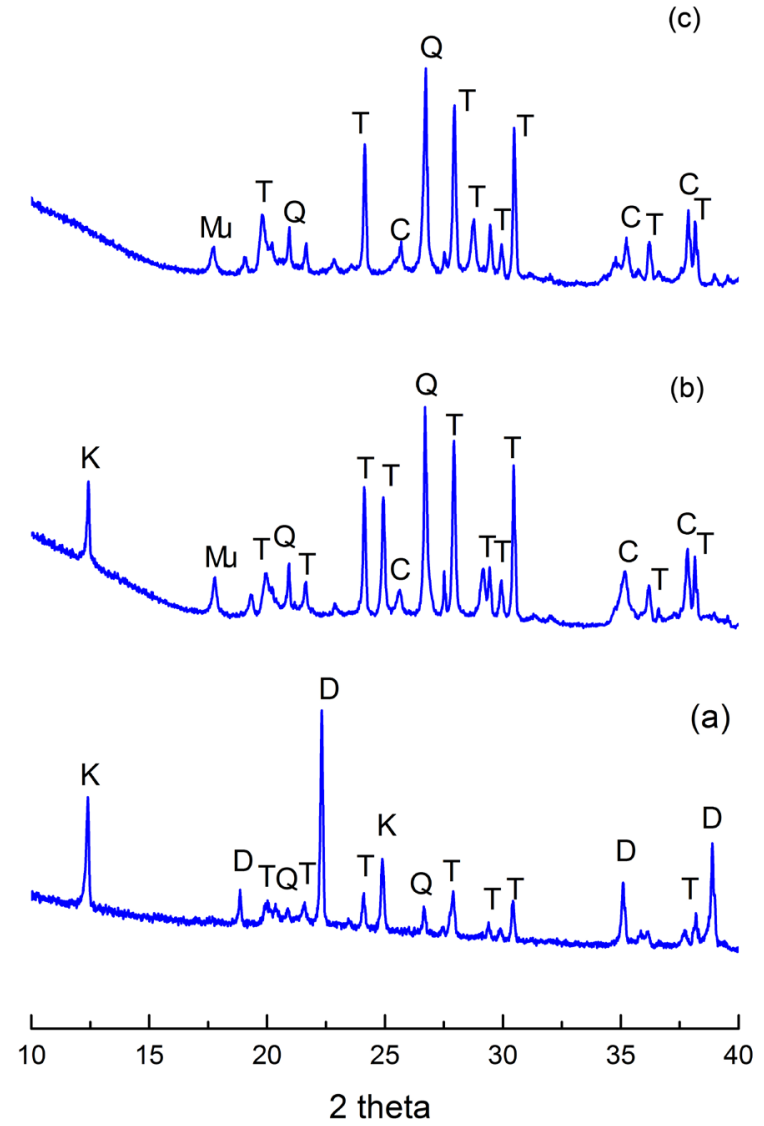

Figure 3. X-ray spectra of the raw G3 sample (a), heat treated at $570^{\circ} \mathrm{C}$ (b) or $700^{\circ} \mathrm{C}$ (c) (K: Kaolinite; Mu: Muscovite; D: Diaspore; T: Topaz; Q: Quartz).

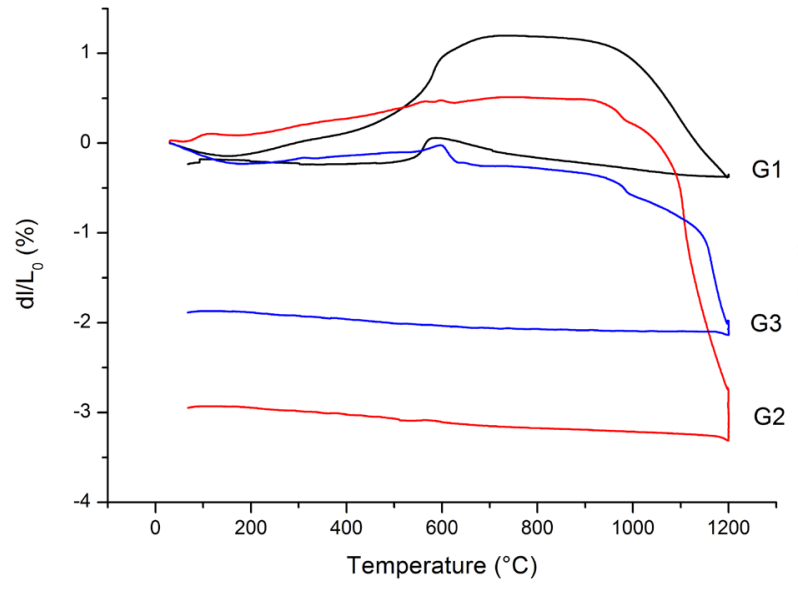

(a)

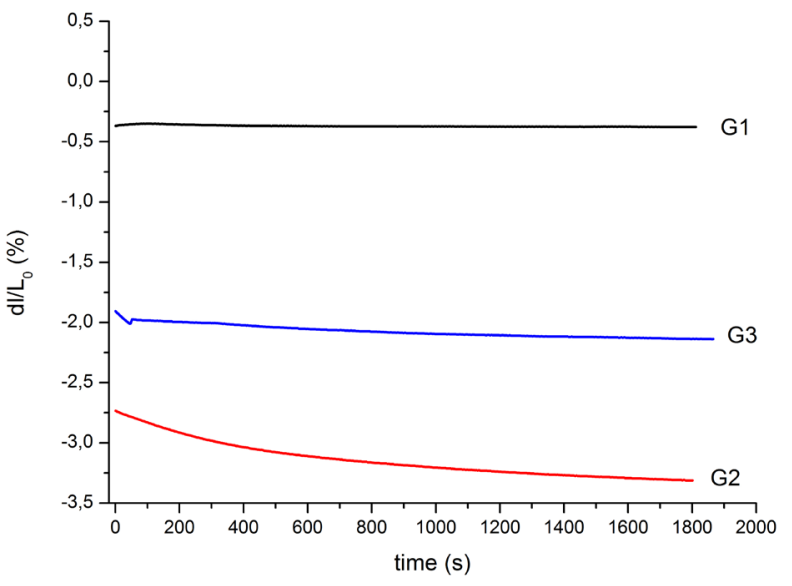

(b)

Figure 4. Dilatometric curves (a), shrinkage vs. time at $1200^{\circ} \mathrm{C}(\mathrm{b})$.

dwell at $1200^{\circ} \mathrm{C}$. The samples G1 and G3 have high dimensional stability at this temperature while clearly G2 flows.

\subsection{Structural Transformations in the Temperature Range $900^{\circ} \mathrm{C}-1200^{\circ} \mathrm{C}$}

G2 and G3 powders were crushed moistened (6\% by weight of water) and then uniaxial pressed using a hydrau- 
lic press to obtain test pieces with dimensions $4 \times 1.5 \times 16 \mathrm{~cm}$. These green briquettes were dried at $105^{\circ} \mathrm{C}$ for $24 \mathrm{~h}$, then for different temperatures $\left(900^{\circ} \mathrm{C}, 1000^{\circ} \mathrm{C}, 1100^{\circ} \mathrm{C}, 1150^{\circ} \mathrm{C}\right.$ and $\left.1200^{\circ} \mathrm{C}\right)$, three briquettes were heated up in a muffle furnace (Nabertherm type) at a rate of $10^{\circ} \mathrm{C} / \mathrm{min}$ and a dwell of 3 hours. The fired samples were then milled for mineralogical investigation by $\mathrm{X}$-ray diffraction (Figure 5).

$\mathrm{X}$-ray data analyses of $\mathrm{G} 2$ and $\mathrm{G} 3$ fired at $1200^{\circ} \mathrm{C}$ reveal the presence of corundum $\left(\alpha-\mathrm{Al}_{2} \mathrm{O}_{3}\right)$, mullite $\left(3 \mathrm{Al}_{2} \mathrm{O}_{3}-2 \mathrm{SiO}_{2}\right)$ and quartz. The reaction mechanism giving corundum and mullite starting from diaspore, topaz and quartz is complex but can be summarized as follows:

- during heating, from $570^{\circ} \mathrm{C}$, corundum issues from the dehydration of the diaspore according to Figure 3(b),

- at $900^{\circ} \mathrm{C}$ the characteristic pics of the topaz are more intense compared to the non-fired sample (Figure 5(b)). The pics associated with muscovite appeared because they were initially obscured by the presence of diaspore (Figure 5(b)). The same applies to the topaz and quartz rays that intensify after the disappearance of the diaspore. This finding is more pronounced in the G3 nuance because it contains more diaspore.

- from $1000^{\circ} \mathrm{C}$ topaz turns into mullite.

\subsection{Mechanical Properties}

The evolution of the flexural strength as a function of the heating temperature is shown in Figure 6(a) and Figure 6(b) for G2 and G3, respectively. For G2, a continued raise is noted in the explored temperature range: 37 $\mathrm{MPa}$ at $1100^{\circ} \mathrm{C}$ up to $48 \mathrm{MPa}$ at $1200^{\circ} \mathrm{C}$. This huge increase is explained by a higher densification (Figure 7(a)
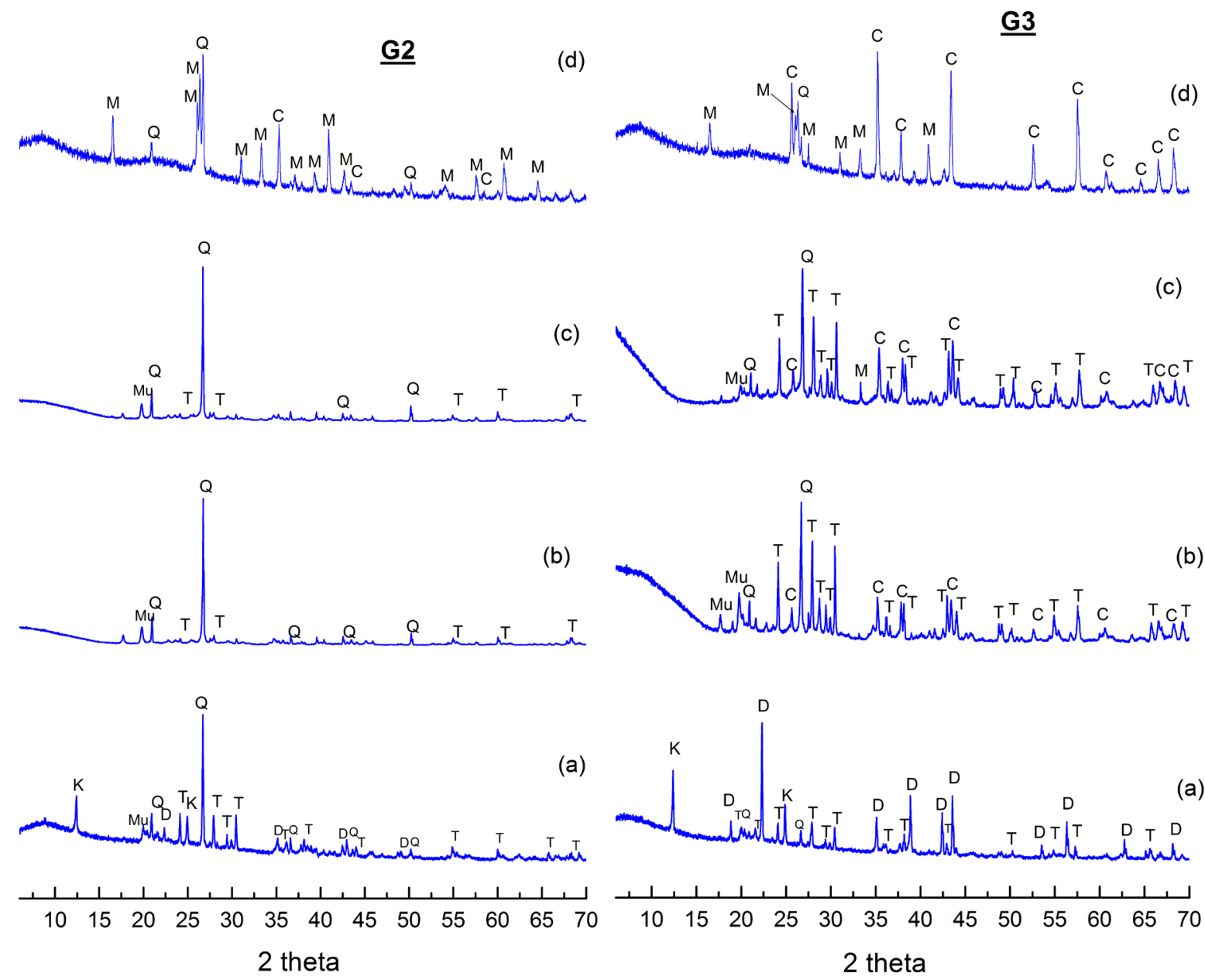

Figure 5. X-ray diffraction spectra of G2 and G3 (a) and after heat treatment at $900^{\circ} \mathrm{C}$ (b), $1000^{\circ} \mathrm{C}$ (c) and $1200^{\circ} \mathrm{C}$ (d). (D: Diaspore; T: Topaz; Q: Quartz; K: Kaolinite; Mu: Muscovite; M: Mullite ; C: Corundum). 


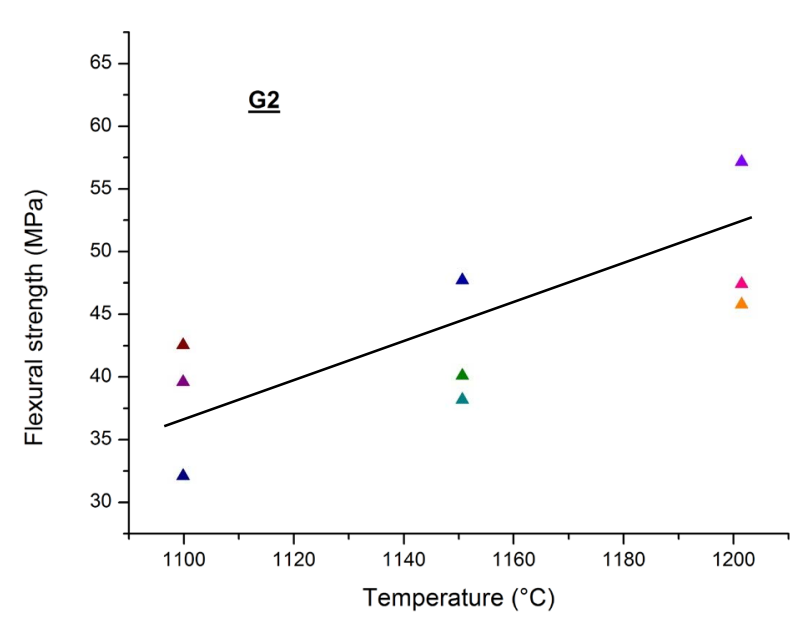

(a)

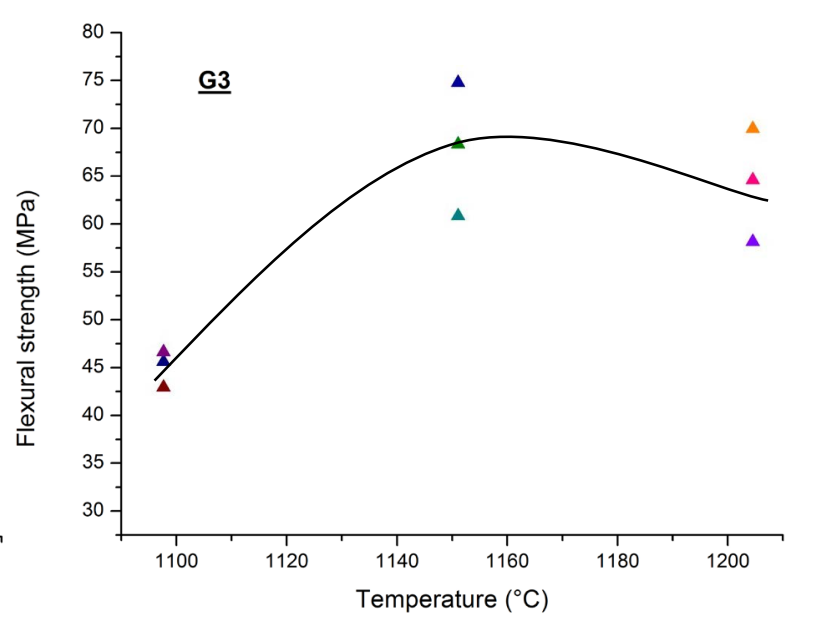

(b)

Figure 6. Evolution of the flexural strength of G2 (a) and G3 (b) as a function of the heating temperature.

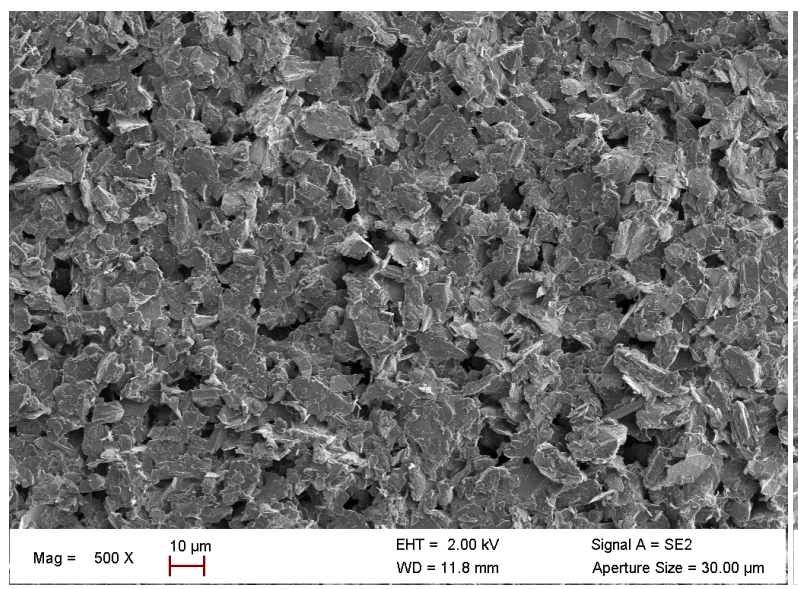

(a)

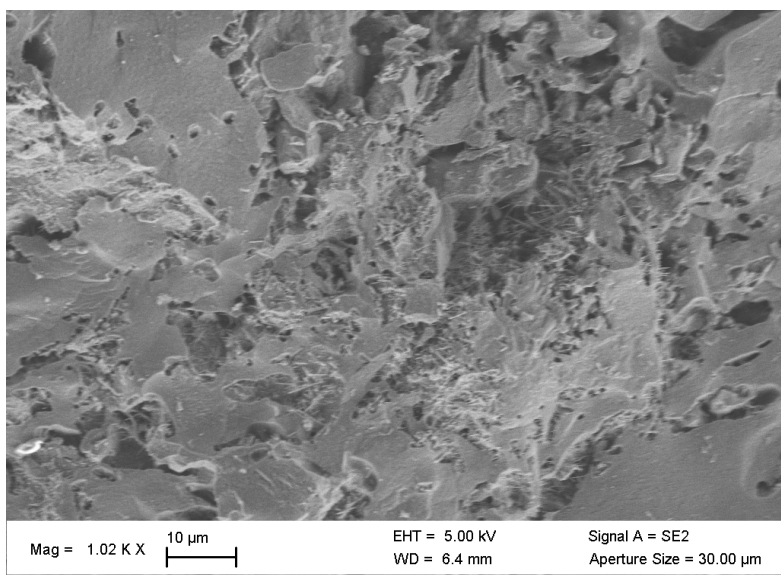

(c)

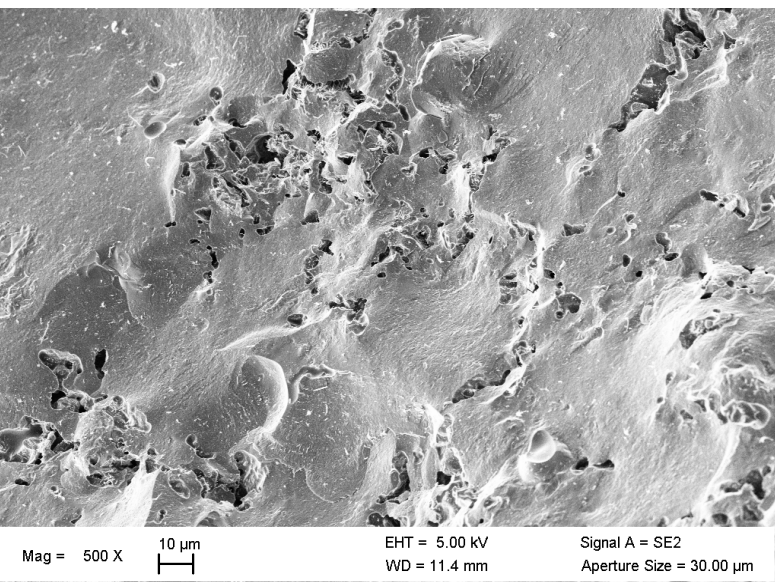

(b)

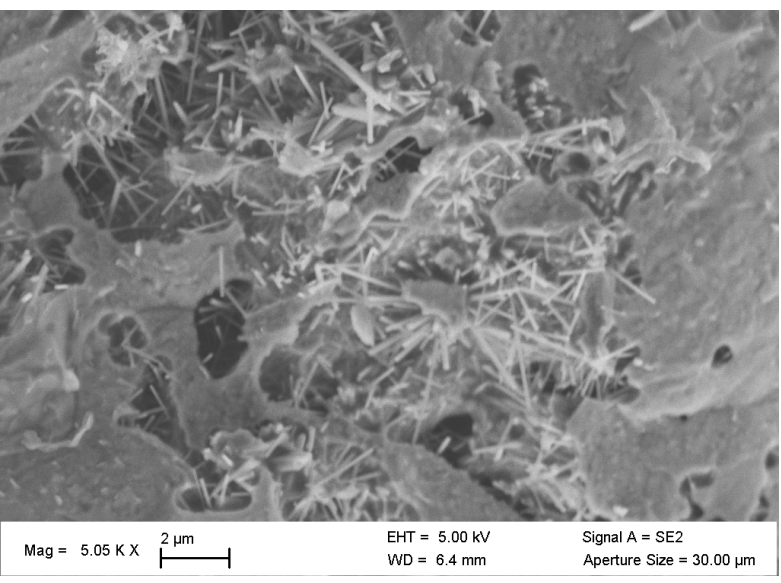

(d)

Figure 7. SEM of G2 (a) (b) and G3 (c) (d) at different temperatures.

and Figure 7(b)). By cons, for G3 the strength increases between $1100^{\circ} \mathrm{C}(47 \mathrm{MPa})$ and $1150^{\circ} \mathrm{C}(70 \mathrm{MPa})$, then seems to decrease $\left(65 \mathrm{MPa}\right.$ at $\left.1200^{\circ} \mathrm{C}\right)$. The higher strengths of $\mathrm{G} 3$ at $1100^{\circ} \mathrm{C}$ is linked to the presence of a glassy phase (Figure $7(\mathrm{c})$ ) while at $1150^{\circ} \mathrm{C}$ it is fostered by a more important crystallization of mullite and corun- 
dum (Figure 5) due to the elevated amount of alumina in this deposit. Figure 7 (d) illustrates this feature. The decreasing trend observed beyond $1150^{\circ} \mathrm{C}$ for G3 may be explained by the gas exhaust associated with the decomposition of topaz present in greater quantity than in G2 (Equation 3).

\section{Discussion}

One feature of the G2 and G3 deposits is their high content of topaz, which allows for the production of mullite. The presence of topaz in the G2 and G3 deposits can be explained by various mechanisms reported in the literature:

- According to Abdel-Rehim A. M. et al. [13] and Shan Liu et al. [14], in the presence of fluorine the formation of topaz between $770^{\circ} \mathrm{C}$ and $800^{\circ} \mathrm{C}$ can occur in different ways:

a) reaction of the quartz and the aluminum fluoride to form fluoro-topaz:

$$
\begin{array}{ll}
2 \mathrm{SiO}_{2}+2 \mathrm{AlF}_{3} \rightarrow \mathrm{Al}_{2}\left(\mathrm{SiO}_{4}\right) \mathrm{F}_{2}+\mathrm{SiF}_{4} \\
\text { Quartz } \quad \text { Fluoro-Topaz }
\end{array}
$$

b) reaction of the corundom (formed at around $500^{\circ} \mathrm{C}$ by transformation of the diaspore) and the quartz with the aluminum fluoride to produce fluoro-topaz:

$$
\begin{array}{r}
2 \mathrm{Al}_{2} \mathrm{O}_{3}+3 \mathrm{SiO}_{2}+2 \mathrm{AlF}_{3} \rightarrow 3 \mathrm{Al}_{2}\left(\mathrm{SiO}_{4}\right) \mathrm{F}_{2} \\
\text { Corundum Quartz } \quad \text { Fluoro-Topaz }
\end{array}
$$

These works also point out that beyond $1000^{\circ} \mathrm{C}$ the decomposition of the fluoro-topaz produces a mix of corundum and mullite:

$$
\begin{array}{cc}
11 \mathrm{Al}_{2}\left(\mathrm{SiO}_{4}\right) \mathrm{F}_{2}+2 \mathrm{AlF}_{3} \rightarrow & 6 \mathrm{Al}_{2} \mathrm{O}_{3}+2\left(3 \mathrm{Al}_{2} \mathrm{O}_{3} \cdot 2 \mathrm{SiO}_{2}\right)+7 \mathrm{SiF}_{4} \\
\text { Fluoro-Topaz } & \text { Corundum } \quad \text { Mullite }
\end{array}
$$

- The works by R. A. Day et al. [12] and other researchers [14] [15] showed that above $1100^{\circ} \mathrm{C}$ mullite can form by the direct decomposition of the topaz (Equation 3). In presence of other sources of fluorine the decomposition of the topaz involves two steps:

$$
\begin{aligned}
& 6 \mathrm{Al}_{2} \mathrm{SiO}_{4}\left(\mathrm{~F}_{0.75} \cdot \mathrm{OH}_{0.25}\right)_{2}+54 \mathrm{SiF}_{4}+27 \mathrm{HF}+27 \mathrm{H}_{2} \mathrm{O} \rightarrow 12 \mathrm{AlOF}+60 \mathrm{SiF}_{4}+42 \mathrm{H}_{2} \mathrm{O} \\
& \rightarrow 2\left(3 \mathrm{Al}_{2} \mathrm{O}_{3} \cdot 2 \mathrm{SiO}_{2}\right)+56 \mathrm{SiF}_{4}+28 \mathrm{HF}+28 \mathrm{H}_{2} \mathrm{O}
\end{aligned}
$$

These literature data help explaining the abundance of topaz in both deposits, together with the main mineral, diaspore, and minority clay phases (muscovite, illite and kaolinite) under the action of a hydrothermal action.

Worldwide, three deposits [11] [16]-[18] consisting mainly of natural sources of aluminum, similar to our case, have been identified. The main mineral phases composing the rocks of these reference deposits are diaspore $(\alpha-\mathrm{AlO}(\mathrm{OH}))$, hydrargillite $\left(\gamma-\mathrm{Al}(\mathrm{OH})_{3}\right)$ and boehmite $(\gamma-\mathrm{AlO}(\mathrm{OH}))$. Other phases are frequently detected as kaolinite, goethite and hematite. These deposits are:

- Guangxi deposit, in the Jingxi region of China [16], consists of a dispersed ore in quaternary laterite in the west of Guangxi. This ore originates from a bauxite horizon in the Permian via physical disruption (faults) and a re-sedimentation process in the quaternary.

- The Goian deposit in Spain (Pontevedra) [17] consists of diaspore (as blue-white natural slices), geographically located in the north-west of Spain.

- The Milas deposit in Turkey [11] [18] consists mainly of a single deposit undergoing primary metamorphism followed by a late re-mobilized hydrothermal and resulting in diaspore formation. The latter was formed during different geological periods.

The deposits investigated in this work are similar to those mentioned above, which are operated industrially.

\section{Conclusion}

Through targeted prospecting, two fields of industrial interest for their high content of diaspore, topaz and quartz 
(as major minerals) and containing kaolinite, illite and muscovite (as secondary minerals) have been identified. Heating up these materials at $1200^{\circ} \mathrm{C}$ yields a mixture of corundum and mullite, two demanded ceramic materials in various industrial fields. The detailed analysis of structural transformations indicates that this result is due to the particular nature of the raw materials that contain certain secondary minerals and fluoride. The presence of the latter is necessary for the formation of sufficient topaz.

\section{References}

[1] Medvedovski, E. (2006) Alumina-Mullite Ceramics for Structural Applications. Ceramics International, 32, 369-375. http://dx.doi.org/10.1016/j.ceramint.2005.04.001

[2] Nicoletto, G., Esposito, L. and Tucci, A. (1997) Wear and Microstructure of Polycrystalline Aluminas. Ceram. Acta, 9, 13-19.

[3] Pask, J.A. (1996) Importance of Starting Materials on Reactions and Phase Equilibria in the $\mathrm{Al}_{2} \mathrm{O}_{3}-\mathrm{SiO}_{2}$ System. European Ceramic Society, 16, 101-108. http://dx.doi.org/10.1016/0955-2219(95)00147-6

[4] Schneider, H., Schrener, J. and Hildmann, B. (2008) Structure and Properties of Mullite-A Review. European Ceramic Society, 28, 329-344. http://dx.doi.org/10.1016/j.jeurceramsoc.2007.03.017

[5] Ruan, G., Zhang, Z., Yin, M. and Xu, G. (2013) Effect of Aluminum Powder on the Synthesis of Corundum-Mullite Composites. Ceramics-Silikaty, 57, 133-137.

[6] Yang, Z., Li, K., Zhao, W. and Zhang, Y. (2011) Preparation of Corundum/Mullite Composites by Sintering. Applied Mechanics and Materials, 84-85, 64-68. http://dx.doi.org/10.4028/www.scientific.net/AMM.84-85.64

[7] Maldhure, A., Tripathi, H.S., Ghosh, A. and Das, S.K. (2013) Mullite-Corundum Composites from Bauxite: Effect of Chemical Composition. Transactions-Indian Ceramic Society, 73, 31-36. http://dx.doi.org/10.1080/0371750X.2013.870050

[8] Bureau de Recherches et de Participations Miniers (1994) Bilan des travaux réalisés sur les argiles de Guenfouda. Office National des Hydrocarbures et des Mines, Rabat.

[9] Wefers, K. and Misra, C. (1987) Oxides and hydroxides of Aluminum. ALCOA. Laboratories-Aluminum Company of America, Paper No. 19.

[10] Yang, H.-M., Yang, W.-G., Hu Y.-H. and Qiu G.-Z. (2003) Kinetics Analysis of Thermal Decomposition Reaction of Diaspore. The Chinese Journal of Nonferrous, 13, 1523-1527.

[11] Hatipoğlu, M., Can, N. and Karali, T. (2010) Effects of Heating on Fire Opal and Diaspore from Turkey. Physica B, 405, 1729-1736. http://dx.doi.org/10.1016/j.physb.2009.12.078

[12] Day, R.A., Vance, E.R. and Cassidy, D.J. (1995) The Topaz to Mullite Transformation on Heating. Journal of Materials Research, 10, 2963-2969. http://dx.doi.org/10.1557/JMR.1995.2963

[13] Abdel-Rehim, A.M. (2012) Thermal and XRD Analysis of Synthesis of Fluoro-Topaz. Thermochimica Acta, 538, 29-35. http://dx.doi.org/10.1016/j.tca.2012.03.006

[14] Liu, S., Liu, J., Zhao, Y., Hou, F. and Du, H. (2014) Microstructure and Properties of the Inter-Locked Corundum/Mullite Structure. Ceramics International, 40, 16825-16828. http://dx.doi.org/10.1016/j.ceramint.2014.07.152

[15] Sabioni, A.C.S. and da Costa, G.M. 2004() Comportamento do mineral topázio a altas temperaturas. Metalurgia and Materiais, 57, 173-176. http://dx.doi.org/10.1590/s0370-44672004000300006

[16] Liu, X., Wang, Q., Zhang, Q., Feng, Y. and Cai, S. (2012) Mineralogical Characteristics of the Superlarge Quaternary Bauxite Deposits in Jingxi and Debao Counties, Western Guangxi. China. Asian Earth Sciences, 52, 53-62. http://dx.doi.org/10.1016/j.jseaes.2012.02.011

[17] Garcia-Guinea, J., Correcher, V., Rubio, J. and Valle-Fuentes, F.J. (2005) Effects of Preheating on Diaspore: Modifications in Colour Centres. Structure and Light Emission. Physics and Chemistry of Solids, 66, 1220-1227. http://dx.doi.org/10.1016/j.jpcs.2005.04.001

[18] Hatipoğlu, M., Helvacı, C., Chamberlain, S.C. and Babalık, H. (2010) Mineralogical Characteristics of Unusual “Anatolian” Diaspore (Zultanite) Crystals from the Ilbirdaği Diasporite Deposit, Turkey. African Earth Sciences, 57, 525-541. 


\section{Submit or recommend next manuscript to SCIRP and we will provide best service for you:}

Accepting pre-submission inquiries through Email, Facebook, Linkedin, Twitter, etc A wide selection of journals (inclusive of 9 subjects, more than 200 journals)

Providing a 24-hour high-quality service

User-friendly online submission system

Fair and swift peer-review system

Efficient typesetting and proofreading procedure

Display of the result of downloads and visits, as well as the number of cited articles

Maximum dissemination of your research work

Submit your manuscript at: http://papersubmission.scirp.org/ 